\title{
Çocuk Acil Servisine Epistaksis ile Başvuran Olguların Klinik ve Laboratuvar Değerlendirmesi
}

\author{
Clinical and Laboratory Characteristics of Pediatric Epistaxis \\ Presenting to the Pediatric Emergency Department \\ Sonay INCESOY ÖZDEMIR ${ }^{1}$, Halise AKÇA², Onur BAHÇECi ${ }^{3}$, Büşra BULUT³
}

1 Yıldırım Beyazıt Üniversitesi, Tıp Fakültesi, Çocuk Sağlığı ve Hastalıkları Anabilim Dalı, Çocuk Hematoloji Onkoloji Bilim Dalı, Ankara,
Türkiye
${ }^{2}$ Yılııım Beyazıt Üniversitesi, Tıp Fakültesi, Çocuk Sağlığı ve Hastalıkları Anabilim Dalı, Çocuk Acil Bilim Dalı, Ankara, Türkiye
${ }^{3}$ Yılııım Beyazı Üniversitesi, Tıp Fakültesi, Çocuk Sağlığı ve Hastalıkları Anabilim Dall, Ankara, Türkiye

\begin{abstract}
ÖZ
Amaç: Bu çalışmada, epistaksis yakınması ile acil servise başvuran pediatrik olguların demografik, klinik, laboratuvar bulgularını ve uygulanan tedavi yaklaşımlarını geriye dönük olarak değerlendirmek, altta yatan ve eşlik eden durumları saptayarak literatür ile karşılaştırmak amaçlanmıştır.

Gereç ve Yöntemler: 1 Ocak 2018-31 Aralık 2018 tarihleri arasında Çocuk Acil Servisine burun kanaması yakınması ile başvuran, 0-18 yaş arasındaki 538 hasta geriye dönük olarak değerlendirildi.

Bulgular: Hastaların 321'i (\%59.66) erkek, 217’si (\%40.33) kızdı. Yaș ortalaması 9.0 \pm 4.7 yıldı. Hastaların en sık ilkbahar aylarında (\%40.66) hastaneye başvurduğu saptandı. Hastaların 532'sinde (\%98.88) kronik hastalık, 517'sinde (\%96.09) ilaç kullanım öyküsü yoktu. En sık neden idiopatikti. Hastaların 420'sinde ( \%78.06) burun kanaması spontan veya hafif baskı ile durmuş ve ek tedavi gereksinimi olmamıştır. 7 (\%1.30) hastaya koterizasyon, 3 (\%0.55) hastaya tampon uygulanmıştır.
\end{abstract}

Sonuç: Bu çalışmada epistaksisin en sık nedeninin idiopatik olduğu saptanmıştır. Erişkinlerden farklı olarak altta yatan sistemik hastalık varlığı çocuklarda nadirdir. Vakaların büyük çoğunluğu spontan veya baskı gibi basit tedavi yöntemleri ile tedavi edilirken az sayıda vaka multidisipliner tedavi yaklaşımlarına gereksinim duyabilmektedir.

Anahtar Sözcükler: Çocuk, Epistaksis, Lösemi

\begin{abstract}
Objective: The aim of this study was to review our institutional experience with the clinical characteristics, laboratory findings, and therapies in children with epistaxis and comparing them with the literature.

Material and Methods: Clinical and laboratory findings of 538 children with epistaxis, admitted at our pediatric emergency department from January 2018 to December 2018, were retrospectively evaluated.

Results: The study group included 538 children diagnosed with epistaxis. 321 (59.66\%) patients were male and 217 $(40.33 \%)$ were female. The mean age at admission was $9.0 \pm 4.7$ years. The most common cause was idiopathic. It was more common in the spring months (40.66\%). There was no history of chronic disease in 532 (98.88\%) of patients and drug use in 517 (96.09\%). Of the 538 patients, initial treatment consisted of nasal cautery (7), nasal packing (3), local pomad (69), or no treatment (420).

Conclusion: This study demonstrated that the most common cause of epistaxis in children is idiopathic. Unlike adults, the underlying systemic disease is rare in children. Epistaxis is controlled with conservative measures in the majority of cases.
\end{abstract}

Key Words: Children, Epistaxis, Leukemia

\section{(1)} INCESOY ÖZDEMIRS ALCCAH BAHCECI O BULUT B
Çıkar Çatışması / Conflict of Interest: Tüm yazarlar adına, sorumlu yazar çıkar çatışması olmadı̆̆ını belirtir.

0000-0003-2863-901X 0000-0003-4990-5735 $0000-0002-2196-6440$ 0000-0002-2196-6440 (Tarih: 26.03.2019 Karar No:/2019/03/11).
Etik Kurul Onayı / Ethics Committee Approval: Bu çalısmada ulusal ve uluslararası etik kurallara uyulmuștur. Bu çalısmada ulusal ve uluslararası etik kurallara uyulmuştur. Çalışma için, Ankara Yıldıım Beyazıt Üniversitesi Yenimahalle Eğitim ve Araştırma Hastanesi Etik Kurulu tarafından onay alınmıştır

Yazarların katkısı / Contribution of the Authors: iNCESOY ÖZDEMiR S: Yazının dizaynı, planlanması, hasta takibinde sorumluluk almak, verilerin değerlendirilmesi, yazının yazılması ve yayın için son onayın verilmesi. AKÇA H: Yazının dizaynı, planlanması, hasta takibinde sorumluluk almak, verilerin toplanması, literatür araștırması, istatistik yapııması. BAHÇECi O: Literatür araştırması, verilerin toplanması, çalışmanın yazımında sorumluluk almak. BULUT B: Verilerin toplanması

Atıf yazım șekli / How to cite : Incesoy Özdemir S, Akça H, Bahçeci O, Bulut B. Çocuk Acil Servisine Epistaksis ile Bașvuran Olguların Klinik ve Laboratuvar Değerlendirmesi. Türkiye Çocuk Hast Derg 2021;15: 1-5.
Yazışma Adresi / Correspondence Address:
Geliş tarihi / Received : 20.10.2020 Kabul tarihi / Accepted : 07.12.2020 Elektronik yayın tarihi : 19.01 .2021 Online published

DOI: $10.12956 /$ tchd.813262 


\section{Giriș}

Burun boşluğunda oluşan kanamalar epistaksis veya burun kanaması olarak tanımlanmaktadır (1). Görülme yaşı bimodal dağılım göstermektedir. Çocuklarda ve yaşlılarda olmak üzere 2 pik görülür. 5 yaş altı çocukların \%30'unda, 6-10 yaş arası çocukların \%56'sında en az bir kez burun kanaması meydana gelmektedir. Ancak bu hastaların \% 10'unun tıbbi yardım aldığı öngörülmektedir. Çocuklarda kanamalar sıklıkla nazal kavitenin anterior bölgesinden kaynaklanmaktadır. Çoğunlukla hafif, tedavi gereksinimi olmayan ve kendi kendini sınılayan burun kanamaları görülse de masif, tekrarlayan ve tedaviye dirençli olan durumlar da saptanabilir (2). Vakaların \% 10'unda etiyoloji saptanamazken, geri kalanında lokal ve sistemik bir çok neden saptanabilir Lokal sebepler; travma/dijital travma, inflamasyon, tümör, septal deformite, yabancı cisim, krut oluşumu, çevresel iritanlar, damarsal malformasyonlar olarak sıralanabilir. Kanama diyatezi/koagulasyon bozukluğu, malignite, vasküler faktörler (diabetes mellitus, hipertansiyon ), karaciğer yetmezliği, ilaç kullanımı gibi çok geniş yelpazede sistemik nedenler de burun kanamasına neden olabilirler. Epistaksisi olan pediatrik olguların \%8-20'sinde altta yatan kanama diyatezi gibi sistemik nedenler saptanabilir ve nadir de olsa hayati tehlikeye yol açan kanamalar görülebilir $(3,4)$.

Bu çalışmada, çocuk acil servisimize epistaksis yakınması ile başvuran olguların demografik, klinik, laboratuvar bulgularını ve uygulanan tedavi yaklaşımlarını geriye dönük olarak değerlendirmek ve literatür ile karşılaştırmak amaçlanmıştır.

\section{GEREÇ ve YÖNTEMLER}

Ankara Yıldırım Beyazı Üniversitesi Yenimahalle Eğitim ve Araştırma Hastanesi Çocuk Acil Servisine, 1 Ocak 2018-31
Aralık 2018 tarihleri arasında burun kanaması yakınması ile başvuran, 0-18 yaş arasındaki 538 hasta geriye dönük olarak değerlendirildi. Her bir olgunun demografik, klinik ve laboratuvar verileri elektronik veri tabanından elde edildi. Hastane veri tabanında "ICD kod: R04.0-epistaksis" tanısı ile arama yapıldı. Demografik bilgileri (yaş, cinsiyet, vb) öyküsü, özgeçmiş ve soygeçmiş bilgileri, fizik inceleme bulguları, laboratuvar parametreleri (hemogram ve koagülasyon testleri), varsa hasta özelinde yapılmış diğer laboratuvar incelemeleri, klinik konsültasyonları ve uygulanan tedavi yöntemleri kaydedildi. Araştırma protokolü Ankara Yıldırım Beyazıt Üniversitesi Yenimahalle Eğitim ve Araştırma Hastanesi Etik Kurulu tarafından onaylandı (Tarih: 26.03.2019 Karar No:/2019/03/11).

\section{İstatiksel Değerlendirme}

Analizlerde SPSS 20 paket programı kullanılmıştır. Tanımlayıcı istatistiklerden faydalanımış olup, veriler $n$ (\%) veya ortalama \pm standart sapma olarak özetlenmiştir.

\section{BULGULAR}

Araştırmaya 538 hasta dahil edildi. Bu hastaların 321'i (\%59.66) erkek, 217'si (\%40.33) kıdı. Yaş ortalaması 9.0 \pm 4.7 yıl arasında değişmekteydi. Hastaların en sık ilkbahar aylarında (\%40.66) hastaneye başvurduğu saptandı. Hastaların başvuru aylarının dağılımı Grafik 1'de verilmiștir. Hastaların 532'sinde (\%98.88) kronik hastalık yoktu. Kronik hastalığı olan toplam beș hastanın üçünde astım, birinde alerjik rinit ve bir hastada idiopatik trombositopenik purpura saptandı. Hastaların 517'sinde (\%96.09) ilaç kullanım öyküsü yoktu. Illaç kullanma öyküsü olan 20 hastanın sekizi (\%1.48) soğuk algınlığı için antigribal ilaç, altısı (\%1.11) oral antibiyotik, üçü (\%0.55) antihistaminik, üçü (\%0.55) lokal steroid kullanmaktaydı. Hastaların hiçbirinde kalitsal kanama diyatezi düşündürecek özgeçmiş öyküsü yoktu

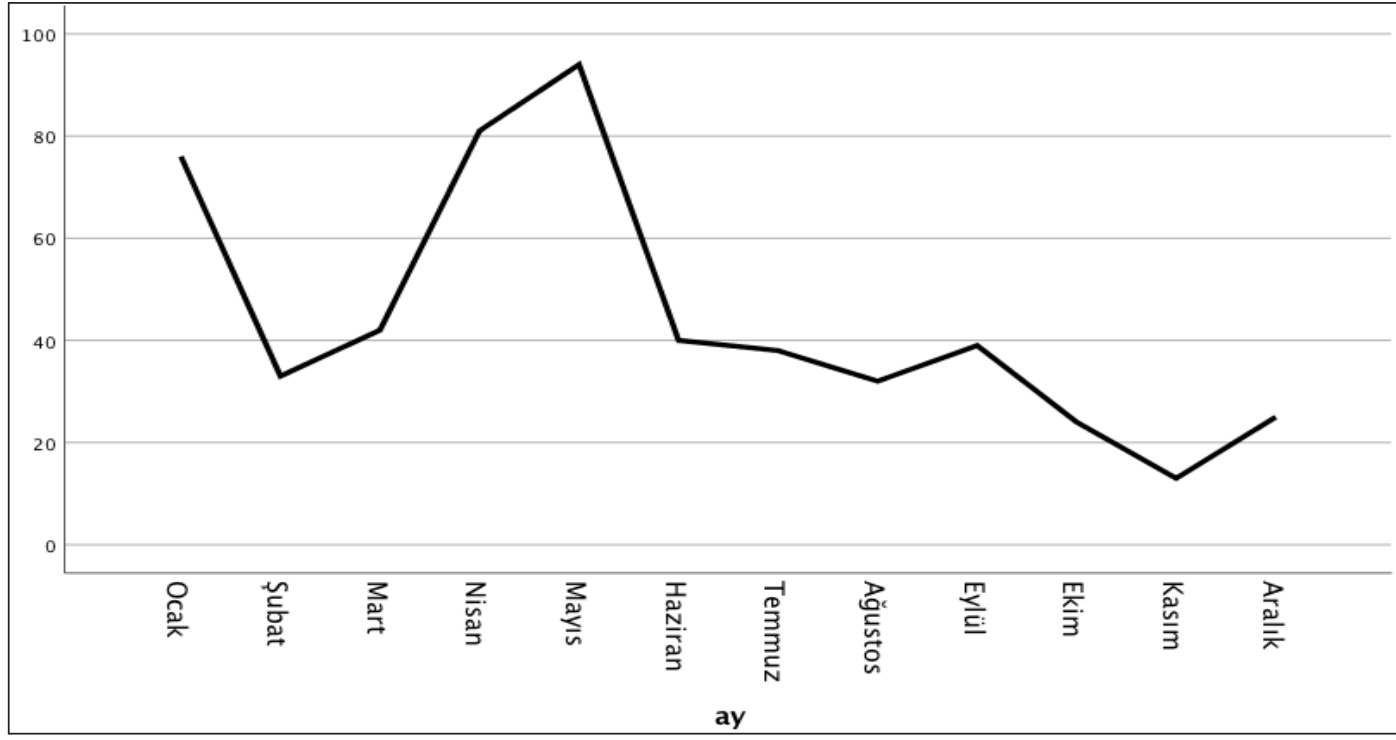

Grafik 1: Epistaksis ile başvuran olguların aylara göre dağııımı. 
Tablo I: Epistaksis yakınması ile bașvuran hastaların laboratuvar sonuçları.

\begin{tabular}{|c|c|c|}
\hline Tetkikler & Min. -Maks. & Ort. \pm SS \\
\hline Hemoglobin (g/dl) & $5.4-18.3$ & $12.9 \pm 1.3$ \\
\hline Beyaz küre $\left(\mathrm{mm}^{3}\right)$ & $3400-290580$ & $9020 \pm 2971$ \\
\hline Trombosit $\left(\mathrm{mm}^{3}\right)$ & $20000-658000$ & $309809 \pm 83628$ \\
\hline PT (sn) & $10.00-17.10$ & $12.46 \pm 0.91$ \\
\hline РТ\% & $58-121$ & $85.2 \pm 10.80$ \\
\hline aPTT (sn) & $20.50-52.10$ & $27.43 \pm 4.21$ \\
\hline INR & $0.84-1.46$ & $1.04 \pm 0.05$ \\
\hline
\end{tabular}

aPTT: aktive parsiyel tromboplastin zamani; INR: uluslarası mormalleştirilmiş oran, PT: protrombin zamanı, Ort. \pm SS: Ortalama Standart Sapma, Min.

-Maks.: Maksimum- Minimum

(göbek kanaması, meno-metroraji, diş çekimi ve/veya cerrahi sonrası kanama, tekrarlayan/uzun süreli müdahale gerektiren kanama). Hastaların hiçbirinin soygeçmişinde kalıtsal kanama diyatezi yoktu.

Kanamanın süresi hastaların 471'inde (\%87.54) 30 dakikadan kısa, 21 'inde (\%3.90) 30-60 dakika arasında, 17'sinde (\%3.15) 1 saat-1 gün arasında, 29'unda (\%5.39) bir günden uzun olduğu bulunmuştur Hastaların epistaksis nedenine yönelik yapılan değerlendirmelerinde; 75 (\%13.94) hastada solunum yolu enfeksiyonu semptomları (öksürük, burun akıntısı, ateş), sekiz hastada (\%1.48) travma öyküsü vardı. Fizik incelemede $39(\% 7.24)$ hastada orofarenks hiperemisi, iki hastada kriptik tonsillit, iki hastada akut otitis media, iki hastada alt solunum yolu enfeksiyonu bulguları ve bir hastada hepatosplenomegali saptandl.

Hastaların tam kan sayımı ve koagülasyon testlerinin verileri Tablo I'de verilmiştir. 411 hastada (\%76.39) biyokimyasal incelemeye gerek görülmemiștir. Biyokimyasal değerlendirme yapılan hastaların hiçbirinde patolojik bulgu saptanmadı. Akut faz reaktanı olarak C-reaktif protein değerinin sadece 27 (\%5.01) hastada yüksek olduğu saptandı.

Hastaların diğer kliniklere konsültasyon oranları incelendiğinde, en fazla Kulak Burun Boğaz Kliniğine (KBB) konsültasyon yapılmıştı (n:225 \%41.82). KBB Kliniğine danışlan 225 hastanın sadece yedisine (\%1.30) müdahale (koterizasyon) gerekmiştir. Çocuk Hematoloji-Onkoloji Kliniğine 14 (\%2.60) hasta yönlendirilmiştir. Bunların altııı hafif düzeyde lökopeni ve trombositopeni nedeniyle yönlendirilmiştir. Viral üst solunum yolu enfeksiyonuna sekonder sitopeni olarak değerlendirilmiștir. $\mathrm{Bu}$ hastaların izleminde sitopenileri düzelmiștir. Yedi hastada demir eksikliği anemisi saptanarak tedavi edilmiștir. Bir hasta kan sayımında hemoglobin $5.4 \mathrm{~g} / \mathrm{dl}$, beyaz küre sayısı 290.580 $\mathrm{mm}^{3}$, trombosit sayısı $20.000 \mathrm{~mm}^{3}$ saptanması nedeniyle Çocuk Hematoloji-Onkoloji Kliniğine danışımış ve akut lenfoblastik Iösemi tanısı almıştır.
Tablo II: Epistaksis ile bașvuran hastalara uygulanan tedavi yöntemleri.

\begin{tabular}{lc}
\hline \multicolumn{1}{c}{ Tedavi Yöntemleri } & n (\%) \\
\hline Tedaviye gerek yok & $421(78.25)$ \\
\hline Lokal nemlendirici & $69(12.82)$ \\
\hline Antibiyotik (oral) & $24(4.46)$ \\
Destek tedavi & $14(2.60)$ \\
Koterizasyon & $7(1.30)$ \\
Tampon & $3(0.55)$ \\
\hline
\end{tabular}

Hastalara uygulanan tedavi yöntemleri Tablo II'de ayrıntılı olarak gösterilmiştir. 69 (12.82) hastaya lokal nemlendirici, eșlik eden bakteriyel enfeksiyonu olan 24 (\%4.46) hastaya oral antibiyotik, 14 (\%2.60) hastaya üst solunum yolu enfeksiyonu için destek tedavi, yedi (\%1.30) hastaya koterizasyon, üç (\%0.55) hastaya tampon uygulanmıștır. Geriye kalan 420 (\%78.06) hastada burun kanaması müdahalesiz veya hafif baskı ile durmuş ve ek tedavi gereksinimi olmamıştır.

\section{TARTIŞMA}

Pediatrik popülasyonda epistaksis yaygın bir sorundur. Çocukların \%60'ı, 10 yaşına kadar en az bir burun kanaması geçirmektedir. Çocukluk çağı epistaksisinin çoğu Kiesselbach pleksusundan kaynaklanır, spontan gelișir, kendi kendini sınırlar ve hastaneye yatıș gerektirmez. Burun kanatlarına 5-10 dakika boyunca hafifçe bastırmak genellikle durması için yeterlidir (5-7). Bu çallşmada, merkezimiz çocuk acil servisine bir ylllık sürede başvuran 538 epistaksis tanılı hastanın bulguları değerlendirilmiștir.

Çocukluk çağında epistaksis yaş, cinsiyet ve mevsimsel değișkenlik göstermektedir. Literatürde erkek çocukların kız çocuklarına oranla daha sık bașvurduğu görülmektedir. Patel ve ark. 'ları (8) tarafından yapılan 359 hastanın değerlendirildiği

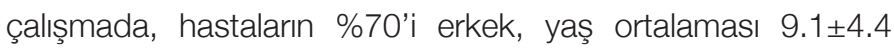
yıl olarak bildirilmiştir. Diğer bir çalışmada burun kanaması ile başvuran 216 hastanın erkek/kız oranı 3:2 olarak bildirimiştir (9). Çalışmamızda, 538 hastanın \%60'ı erkek ve yaş ortalaması $9.0 \pm 4.7$ yll olarak bulunmuştur. Serimizde bir yaş altı yalnızca bir olgu bulunmaktadır. Sonuçlarımız literatür ile uyumludur. Literatürde, bazı çalışmalarda epistaksisin tüm mevsimlerde eşit olduğu görülürken bazı çalışmalarda ise sonbahar ve kış aylarında sıklı̆ın arttığı bildirilmektedir (2,8-10). Bu çalışmalar, soğuk hava, tekrarlayan solunum yolu enfeksiyonu ve iç mekan ısıtması ile olușan kuru hava nedeniyle burun kanaması insidansının kışın en yüksek olduğunu kanıtlarken, mevsim boyunca eșit derecede burun kanaması olduğunu gösteren çalışmalar bu sonucu bölgesel iklim ve çevresel faktörlerle ilişkilendirmektedir. Seidel ve ark.'ları (11) tarafından yapılan çalışmada, epistaksis sıklığının kış aylarında arttığı görülmüştür. Başka bir çalışmada ise hastalarda burun kanamasının en sık 
ilkbahar aylarında görüldüğü bildirilmiş̧ir (12). Çalışmamızda da burun kanaması ile başvuru sıklığının kış ve ilkbahar aylarında (\%40.66) arttığı gözlemlenmiştir.

Epistaksis tanılı hastaların detaylı anamnezlerinde kanama sürelerinin genellikle kısa süreli olduğu görülmektedir. Davies ve ark.'larının (7) 50 olgu içeren çalışmasında kanama süresi; hastaların \%60'ında 5 dakikadan kısa, \%28'inde 5-10 dakika arasında ve \%12'sinde 10 dakikadan uzun olduğu belirtilmiştir. Çalışmamızda, burun kanamasının süresi; \%87.54'ünde 30 dakikadan kısa, \%3.90'ınde 30-60 dakika arasında, \%3.15'inde 1 saat-1 gün arasında, \%5.39'unda bir günden uzun olduğu bulunmuştur. Her iki çalışmanın sonuçları kanama sürelerinin çoğunlukla kısa süreli olduğunu destekler niteliktedir.

Epistaksis tanılı hastaların etiyolojik nedenleri arasında çevresel faktörler, lokal ve sistemik nedenler bulunmaktadır. Burun kanamasına neden olan travma, enflamatuar hastalıklar (sinüzit, alerjik rinit, viral üst solunum yolu enfeksiyonları), septal patolojiler, tümörler, anevrizmalar, koagülasyon bozuklukları, trombositopeniler, hormonal nedenler ve kardiyovasküler nedenler gibi birçok lokal ve sistemik neden bulunmaktadır $(13,14)$. Sistemik sebeplere bağlı epistaksis genelde tekrarlayıcı niteliktedir. Bilal ve ark.'ları tarafından yapılan çalışmada, epistaksis tanılı hastaların \%69.4'ünün ek şikayetinin olmadığı, \%31.6'sında ise en sık üst solunum yolu enfeksiyonu ve alerjik rinit görüldüğü bildirilmiştir. Bu çalışmada hastalarda travma öyküsü bulunmamakta ve hastaların \%24.7'sinde kronik hastalık mevcuttur (15). Çalışmamızda, hastaların \%82.71'unun ek yakınmasının olmadığı, en sık üst solunum yolu enfeksiyonunun (\%12.45) görüldüğü, travmanın yalnızca sekiz hastada (\%1.48) bulunduğu ve hastaların \%99'unda kronik hastalık bulunmadığı saptanmıştır. Ek olarak, ilaç kullanım öyküsü de anamnezde sorgulanması gereken önemli durumlardan biridir. Damrose ve ark.'ları tarafından yapılan çalışmada, 90 hastanın \%31'inde ilaç kullanım öyküsü mevcuttur (16). En sık \%68 oranla nonsteroid antiinflamatuvar ilaç (NSAID) kullanımı görülmüştür. Serimizde ise hastaların \%96.09'unun ilaç kullanım öyküsü bulunmamaktadır.

Çocukluk çağı epistaksis değerlendirmesinde, detaylı bir anamnez, fizik muayene, laboratuvar testleri ve etkili tedavi yöntemleri ile birlikte multidisipliner bir yaklaşım gerekmektedir. Damrose ve ark.'ları (16) tarafından yapılan çalışmada, fizik muayenede hastaların, \%67'sinde anormallik saptanmışır ve bu hastaların da \%60'ında görülebilir damarlar, kabuklanma, septum deviasyonları olduğu bildirilmiştir. Çalışmamızda ise, hastaların \%92'sinin fizik muayenesi dosya kayıtlarında "sistem muayeneleri normal" olarak belirtilmiştir. Bu sonuç, sistemik muayenenin bir parçası olan nazal muayenenin pediatrik acil servislerde ayrıntılı olarak yapılıp kaydedilmesi gerektiğini göstermektedir. Bu eksikliğin en önemli nedenlerinin, pediatrik acil servislerdeki hasta yoğunluğu, deneyimli personel azlığı ve teknik alt yapı yetersizliği olduğunu düşünmekteyiz.
Çalışmamızda KBB kliniğine konsültasyon oranı \%41.82'dir. Bu oranın yüksekliği yukardaki savımızı desteklemektedir. Elden ve ark.'ları (17) tarafından yapılan çalıșmaya göre 47 epistaksis tanılı hastanın, \%8.5'inde anemi saptanmış ve \%32'si Çocuk Hematoloji polikliniğine konsülte edilmiştir. Serimizde Çocuk Hematoloji-Onkoloji Kliniğine konsültasyon oranı \%2.60'dır. Bunların yaklaşık yarısı viral üst solunum yolu enfeksiyonuna sekonder sitopeni, diğer yarısı demir eksikliği anemisi olarak değerlendirilmiştir. Epistaksis yakınması ile başvuran bir hasta ise akut lenfoblastik lösemi tanısı almıştır.

Kanamanın derecesi, yeri, klinik durum ve etiyoloji tedavide ilk müdahalenin şeklini belirlemektedir. Çoğu burun kanaması hafiftir ve genelllikle spontan veya basit önlemlerle durur. Öncelikle hasta sakin bir şekilde oturtulur, posteriora kan gitmesini önlemek için öne doğru eğilir, burun kanatları iki parmak arasında sıkılarak baskı uygulanır. Bir çalışmada, hastaların \%72'sinde pozisyon, basınç uygulaması ve buz uygulaması gibi tedavi yöntemleri uygulanırken, \%28'inde ise anterior nazal tampon tedavisi uygulanmıştır (18). Başka bir çalışmada, fibrin yapıştııı ı kullanımı ile koterizasyon ve tamponlama uygulanıp kanamanın kontrol edilemediği pıhtılaşma bozukluğu olan 10 hastayı, etkili bir şekilde tedavi ettiklerini bildirmişlerdir (19). Çalışmamızda da literatür ile uyumlu olarak hastaların \%79'unun herhangi bir ileri tedavi yöntemine intiyacı bulunmamaktaydı. Kulak Burun Boğaz polikliniğine danışlan hastaların sadece \%3'ünün spesifik tedavi intiyacı olduğu saptandı

Çalışmamızda çocukluk yaş grubunda epistaksisin en sık kış ve ilkbahar aylarında üst solunum yolu enfeksiyonuna eşlik ettiğini saptadık. Erişkinlerden farklı olarak altta yatan sistemik hastalık varlığının çocuklarda nadir olduğunu gösterdik. Bu nedenle, çocuklarda gereksiz laboratuvar incelemelerinden kaçınılmalıdır. Ayrıntilı hematolojik ve biyokimyasal testler anamnez ve fizik muayenede sistemik hastallk ve kanama diyatezi düşündüren ek yakınma ve bulgu varlığında, tekrarlayan, uzun süren ve ağır seyreden kanamalarda planlanmalıdır.

Çalışmamızın en önemli kısıtlığı retrospektif planlanmasıdır. Bu nedenle detaylı klinik veri eksikliği vardır ve olguların tedavi takibi yapılamamıştır.

Sonuç olarak, Çocuk Acil Polikliniğine epistaksis yakınması ile başvuran hastalara yaklaşımda öncelik kanamanın kontrol altına alınmasıdır. Kanama durdurulduktan sonra burun kanamasına neden olabilen çevresel, lokal ve sistemik nedenler detaylıca sorgulanmalıdır. Detaylı fizik incelemenin ardından gerekiyorsa laboratuvar ve görüntüleme tetkikleri istenerek nedene yönelik tedavi yöntemi belirlenmelidir. Vakaların büyük çoğunluğunda, kanama müdahalesiz veya baskı gibi basit tedavi yöntemleri ile kontrol edilirken az sayıda vaka multidisipliner tedavi yaklaşımlarına gereksinim duyabilmektedir. 


\section{KAYNAKLAR}

1. Özcan C. Epistaksis. İçinde: Koç C, editör. Kulak Burun Boğaz Hastalıkları ve Baş Boyun Cerrahisi. Birinci Baskı, Ankara, Güneş Kitabevi, 2004: 479-93.

2. Brown NJ, Berkowitz RG. Epistaxis in healthy children requiring hospital admission. Int J Pediatr Otorhinolaryngol 2004;68:1181-4.

3. Gifford TO, Orlandi RR. Epistaxis. Otolaryngol Clin North Am 2008;41:525-36.

4. Al Khtoum N, Al Roosan M. The evaluation of conservative measures in the treatment of epistaxis. Khartoum Med J 2008;1:15-7.

5. Ahmed EA, El-Magd EAA, Hasan GM, El-Asheer OM, A comparative study of propranolol versus silver nitrate cautery in the treatment of recurrent primary epistaxis in children. Adolesc Health Med Ther 2015;30:165-70.

6. Diamond L. Managing epistaxix. JAAPA 2014;27:35-9.

7. Davies K, Batra K, Mehanna R, Keogh I. Pediatric epistaxis: Epidemiology, management and impact on quality of life. Int $\mathrm{J}$ Pediatr Otorhinolaryngol 2014; 78:1294-7.

8. Patel N, Maddalozzo J, Billings KR. An update on management of pediatric epistaxis. Int J Pediatr Otorhinolaryngol 2014;78:1400-4.

9. Misra A, Basu A, Mandal PK, Mahapatra NC. Management of pediatric epistaxis in different age group in tertiary care centre. Int $J$ Contemp Pediatr 2016;3:1206-9.
10. Ying-Xia L, Jie-Qiong L, Qing-Long G, Pang C, Huang CL. Pediatric Epistaxis and Its Correlation Between Air Pollutants in Beijing From 2014 to 2017. Ear Nose Throat J 2020;99:513-7.

11. Seidel DU, Sesterhenn AM, Kosdev K. Seasonal Variation of Epistaxis in Germany. J Craniofac Surg 2018;29:365-7.

12. Kaygusuz I, Karlıdağ T, Keleş E, Yalçın Ş, Alpay HC, Sakallığlu Ö. Hastaneye yatırılarak tedavi edilen 68 epistaksisli hastanın retrospektif analizi. Fırat Tıp Dergisi 2004;9:82-5.

13. Svider $P$, Arianpour K, Mutchnick S. Management of epistaxis in children and adolescents. Pediatr Clin N Am 2018; 65:607-21.

14. Ada M, Işlak C, Canbaz E, Aydın H, Yüksel S, Akar Z. Epistaksis nedeni olarak intrakranial internal karotid arter pseudoanevrizması. Türk Otolaringoloji Arşivi 1994;32:209-11.

15. Bilal N, Acıpayam C, Orhan I, Sağıroğlu S. Çocuklarda epistaksis nedenleri ve prognostik faktörler. Kocaeli Med J 2018;7;2:103-8

16. Damrose JF, Maddalazzo J. Pediatric epistaxis. Laryngoscope 2006;116:387- 93.

17. Elden V, Reinders M, Witmer C. Predictors of bleeding disorders in children with epistaxis: value of preoperative tests and clinical screening. Int J Pediatr. Otolaryngol 2012;76:767-71.

18. Razdan U, Raizada RM, Chaturvedi VN. Efficacy of conservative treatment modalities used in epistaxis. Indian J Otolaryngol Head Neck Surg 2004;56:20-2.

19. Walshe P, Harkin C, Murphy S, Shah C, Curran A, McShanee D. The use of fibrin glue in refrectory coagulopathic epistaxis. Clin Otolaryngol 2001;26:284-5. 